Alternative governance arrangements for modular water infrastructure: An exploratory review

Journal Article

Author(s):

Pakizer, Katrin (D); Lieberherr, Eva (D)

Publication date:

2018-03

Permanent link:

https://doi.org/10.3929/ethz-b-000309237

Rights / license:

In Copyright - Non-Commercial Use Permitted

Originally published in:

Competition and Regulation in Network Industries 19(1-2), https://doi.org/10.1177/1783591718814426

Funding acknowledgement:

172366 - Challenges and Opportunities of Modular water Infrastructures for Greening the Swiss Economy (COMIX) (SNF) 


\title{
Alternative governance arrangements for modular water infrastructure: An exploratory review
}

\author{
Katrin Pakizer ${ }^{\mathrm{a}}$ and Eva Lieberherr ${ }^{\mathrm{a}}$ \\ ${ }^{\mathrm{a}}$ Swiss Federal Institute of Technology in Zurich (ETH Zurich), Switzerland
}

Please cite as: Pakizer, K. and Lieberherr, E. (2018) "Alternative governance arrangements for modular water infrastructure: An exploratory review", Competition and Regulation in Network Industries, Vol. 19(1-2), 53-68

DOI: $10.1177 / 1783591718814426$

\begin{abstract}
This article presents an exploratory review of alternative governance arrangements for modular systems in the urban water sector in terms of policy instruments, organizational structure, and underlying mechanisms. We develop an analytical framework to review the literature on alter- native arrangements for innovative technologies. The preliminary results highlight the importance of governmental involvement and formal policy instruments to ensure public and environmental health in the context of modular water infrastructures. This is in line with the status quo of conventional water governance arrangements. However, the findings also suggest that informal instruments supplement the formal ones and that instead of political-administrative accountability more horizontal mechanisms, such as answerability toward citizens and consumers, play an important role in the context of new water technologies.
\end{abstract}

\section{Keywords \\ Governance, modular infrastructure, urban water systems}

\section{Introduction}

Current urban water infrastructures are increasingly exposed to aging transportation lines, outdated technology, climate change, population growth, and urbanization. Due to their largescale, centralized structures, and traditionally hierarchical governance approaches, these systems usually lack the flexibility to cope with those challenges (Larsen, Hoffmann, Lüthi, Truffer, \& Maurer, 2016; van de Meene, Brown, \& Farrelly, 2011). Recent technological advances in the form of modularized systems could enable radically different and potentially more sustainable, adaptive, and economically efficient water infrastructures (Dahlgren, Göcmen, Lackner, \& Van Ryzin, 2013; Larsen, Lienert, \& Udert, 2013). Modular systems consist of single modules that are mass-produced (economies of number units) and increasingly automate (Dahlgren et al., 2013). They share commonalities with decentralized on-site and small-scale solutions, which challenge centralized water infrastructures and hierarchal governance approaches. For the purpose of this article, we consider modular systems a type of decentralized infrastructure and consequently posit that observations and 
lessons learned can be applied interchangeably. Most Organization for Economic Cooperation and Development (OECD) countries, however, continue to rely on the tried-andtrue centralized solutions and, consequently, the implementation of modularized water systems remains limited (OECD, 2007; van de Meene et al., 2011).

Two reasons are set forth in the literature addressing this non-implementation of feasible technological solutions. One explanation proposes that infrastructure sectors are characterized by the existence of socio-technological regimes prone to lock-in tendencies once they are established, often leading to the so-called "innovation deficit" (Krozer, Hophmayer-Tokich, van Meerendonk, Tijsma, \& Vos, 2010; Trapp, Kerber, \& Schramm, 2017). In the case of the water sector high upfront investments, potential risk of sunk costs and high asset durability (typical lifespans of 30 to 100 years) lead to path dependence that seems to favor conventional urban water structures (Finger, Groenewegen, \& Künneke, 2005; Markard, 2011; Trapp et al., 2017; Truffer, Binz, Gebauer, \& Störmer, 2013). Another specificity of the sector is that water is a vital and non-substitutional good for humans and the environment, raising strong expectations for service pro- visions' reliability and high resource quality (Daniell, Rinaudo, Chan, Nauges, \& Grafton, 2015; Holmes, 2000; Lieberherr \& Fuenfschilling, 2016). Consequently, the political and economic transaction costs associated with altering the hierarchical organization of water services may lead to "status quo bias," and therefore inhibit change (Moshinsky \& Bar-Hillel, 2010; Pérard, 2009).

The second explanation posits that the innovation deficit can be related to a limited understanding of the different forms of governance and regulation needed to support alternative approaches and technologies (Kiparsky, Sedlak, Thompson, \& Truffer, 2013; van Meene et al., 2011). This argument is supported by theories of coevolution or realignment, which state that technological and organizational change have to evolve in an interrelated manner (Crettenand \& Finger, 2013; von Tunzelmann, 2003). In other words, the transformation toward more sustainable service provision and resource management requires the joint development of technological and institutional designs (Crettenand \& Finger, 2013; Kiparsky et al., 2013; Trapp et al., 2017). The lack of alternative governance arrangements, however, could also result from public service providers' pursuit of static efficiency. Due to the uncertainty associated with innovation and the general behavioral tendency of loss aversion, ${ }^{1}$ static efficiency remains an easier "political sell" than innovative governance approaches (Potts, 2009). To implement modular water infrastructure, new regulations and institutional arrangements need to be developed while others may become obsolete, following the premises of flexibility, adaptability, and dynamic efficiency (Araral \& Wang, 2013; Ménard \& Saleth, 2012; Potts, 2009).

In traditional centralized systems, water users have typically been serviced by the municipality, where the rules of the game are highly formalized, that is, the central government makes the overarching regulations in terms of quality, and so on, and the operational domain is typically delegated to municipal authorities (Lieberherr, 2012). The implementation of modularized water infrastructure challenges such top-down structures, as it encourages more self-organization and local autonomy (Daniell et al., 2015). The assumption

\footnotetext{
1 "Loss aversion" describes the tendency to value a statistically equivalent expected loss higher than the corresponding statistical gain (Moshinsky \& Bar-Hillel, 2010; Potts, 2009).
} 
is that regulation and governance arrangements become adapted in the case of modularized infrastructure, with less hierarchical government involvement. As a result, users could benefit from increased choices (e.g. concerning installation or maintenance), but it also leads to more responsibilities on the individual scale, as the current operators and representative institutions may have less influence. This could also affect mechanisms, such as accountability, which might take on a more horizontal and market-based form uncoupled from direct governmental control (Daniell et al., 2015).

Consequently, the effective application of technology and its proper functioning is dependent on regulation and governance systems that enable the integration of innovations in the existing landscape (Tropp, 2007). ${ }^{2}$ Despite the understanding that governance is important for the successful introduction of novel technology, there is little insight into its processes and effects in the context of modular, decentralized infrastructure (Goulden, Portman, Carmon, \& Alon-Mozes, 2018; van de Meene et al., 2011). We therefore conduct an exploratory review of alternative governance and regulatory arrangements for modular water systems in OECD countries and emerging economies. We thus assess what policy instruments and organizational structures are used and what the central mechanisms are at play in the context of modularized, small-scale and decentralized infrastructure. Ultimately, this provides us with insight regarding what types of governance arrangements are conducive for modularized technologies.

The article is structured accordingly: In the next section we develop an analytical framework, which serves as the basis for a systematic investigation of alternative governance modes in the literature. We then outline our methods, before presenting our results on the exploratory literature review. We finally conclude by highlighting our key findings and discussing considerations for future research.

\section{Analytical framework}

Analytically, we want to understand the link between governance and modular, decentralized infrastructure. In this article, we focus on the former, while treating the latter largely as a contextual factor. Since scholars have challenged the hierarchical command and control structures of public administration at the end of the last century, the meaning of governance has shifted to signify new processes of governing (Stoker, 1998). The role of this shift and its consequences for the relation between governance and government polarizes the literature on governance and public administration. For instance, some scholars understand governance as an evolution from traditional government approaches, perceiving it as a new form of governing complex systems that leaves the "old"' one behind as illustrated by titles such as "'The New Governance: Governing without Government' (see Rhodes, 1996, 2007; Stoker, 1998). Other scholars argue that the government remains crucially important (e.g. as facilitator or collaborator), as the presence of governance only transforms the state's role without rendering it irrelevant for public administration (Holley, Gunningham, \& Shearing, 2012; Hysing, 2009; Lundqvist, 2001; Pierre \& Peters, 2000; Sørensen, 2006). Following the

\footnotetext{
${ }^{2}$ Converting all current water distribution structures may not be economically feasible or socially desirable, which is why we assume a hybrid system including likewise large-scale and small-scale (modularized) water infrastructure (Lee et al., 2014).
} 
later school of thought, we understand governance as part of a continuum between government and governance along which the role of the state varies from direct state intervention to extensive societal autonomy (Hysing, 2009; Lieberherr, Klinke, \& Finger, 2012; Lieberherr, 2012). Governance is characterized by a greater reliance on nonhierarchical, informal instruments, the involvement of a plurality of actors (public and private) that form more or less interconnected governance networks and the drive for adaptive change (Burris, Drahos, \& Shearing, 2005; He' ritier, 2002). The presence of diverse actors and instruments challenges the established structures and steering means between actors, resulting in a need for a plurality of mechanisms that ensure service provision (Burris et al., 2005). As the governance perspective focuses, in particular, on instruments, actors, and processes, it provides us with a framework for examining changes in the (public) administration of decentralized, modular water services. Accordingly, we differentiate between the following three governance aspects. First, we address differing types of policy instruments. Second, we consider the actors, which we understand as the organizations that manage and provide public services, those responsible for the oversight and regulation of the services as well as additional public and private actors including civil societal ones. Finally, we address the process aspect through the notion of mechanisms, which shed light onto the interactions between the actors and instruments in the form of accountability means or social norms, for example. We explain each of these analytical components below.

Policy instruments constitute a toolbox used by policy actors to steer the behavior of actors (policy addressees) to reach predefined goals (Ingold, Lieberherr, Schläpfer, Steinmann, \& Zimmermann, 2016). We differentiate between formal and informal instruments based on the level of enforceability by the government. Formal instruments are legally binding typically with direct governmental intervention. These are either legally mandated (regulatory instruments) or become binding once activated by an addressee (market-based instruments). In contrast, informal instruments are not legally binding, being instead of a rather voluntary, informative or collaborative nature. In environmental governance, a combination of different policy instruments - a policy instrument mix, rather than single tools - is common, while formal instruments predominate (Ingold et al., 2016; Lascoumes \& Le Gales, 2007).

Service provision can occur through different organizational forms, depending on management style, ownership, and levels of embeddedness in the political and regulatory system (Lieberherr, 2012). Public actors can provide services directly, delegate them at arm's length, co-manage in the form of Public-Private Partnerships (PPPs) — so-called joint ventures - or divest the tasks to private actors. The degree of state involvement in the management of public services ranges from: direct public, delegated public, delegated private to direct private (Bovaird, 2010; Lieberherr, 2012). PPPs fall within the delegated private mode and are characterized by shared ownership between public and private actors, while the actual service provision typically occurs through private actors (OECD, 2009; Thom \& Ritz, 2006). Ownership is closely dependent on a specific combination and allocation of rights and responsibilities among actors, ranging from public, private, community to shared ownership (Schneider \& Jäger, 2001). The status quo of conventional water governance today is public management and ownership (Dominguez, Worch, Markard, Truffer, \& Gujer, 2009). Similarly, different organizations can regulate the service providers - typically, these have been governmental departments or agencies at regional and national levels in the water sector, 
but these can also be semi-independent regulators (at arm's length from the governmental actors) (Lieberherr \& Truffer, 2015).

Finally, mechanisms in the form of principles, norms and values shape the interplay between policy instruments and actors (Grigg, 2011). For instance, conventional governance arrangements of large and centralized water systems traditionally rely on the principle of political-administrative accountability, where agents (service providers) are accountable to a principal (elected representatives or public servants) through formal regulatory instruments (Kjær, 2004). In the context of governmental reforms including contracting-out and privatization, "accountability [has become] a spread between multiple actors and institutions" (Hodge \& Coghill 2007, p. 678). Often layered on already existing forums of accountability, new forums such as agencies, financial investors (share- holders), customers via exit and choice, and the media can play a pivotal role in holding service providers to account (Klenk \& Lieberherr, 2014). Similarly, modular water systems could entail differing accountability forms, beyond vertical, political-administrative accountability, such as electorate or consumer accountability as it requires more cooperation and self-governance (Daniell et al., 2015; Pahl-Wostl, 2007).

Besides accountability, norms, in particular social norms, can shape the interplay between actors and instruments (Piskorski \& Gorbatai, 2017). As a type of informal rule, social norms can determine what kind of behavior is deemed appropriate or acceptable, encouraging behavioral changes and adaptation in the case of norm violation, while rewarding norm conformity. The violation of social norms decreases social acceptance and can lead to public scrutiny. For instance, an unreasonable tariff structure could conflict with the principle of water affordability and the perception of fairness. In this context, the activating of particular values can be crucial for public acceptance of a tariff structure or modular water systems in general. Hedonic values, which focus on improving personal feelings and reducing effort, seem to be particularly significant for under- standing environmentally relevant attitudes, preferences, and actions (Steg, Perlaviciute, van der Werff, \& Lurvik, 2014). However, despite the growing recognition of the role of such mechanisms, there is still little research on how actors influence and are influenced by values and norms (Purtik \& Arenas, 2017) and particularly in the context of new water technologies.

Empirically, we are interested in finding "alternative" governance arrangements that stand out, due to their innovative application of more informal policy instruments or new organizational forms in the context of modularized, decentralized infrastructure. Furthermore, we aim to identify mechanisms in the form of principles, norms, or values in the context of new arrangements and draw a link for how these are conducive for modular, decentralized technologies (Kinzig et al., 2013; Pilbeam, Alvarez, \& Wilson, 2012).

\section{Methods}

Our research focus is on the governance and regulation of modular, decentralized, distributed, or small-scale water systems. We synthesize secondary data generated through an exploratory literature review to identify alternative governance arrangements based on the review technique by Pilbeam, Alvarez, and Wilson (2012). The search follows a predetermined series 
of steps consisting of planning, searching, screening, extraction, synthesis, and reporting (Pilbeam et al., 2012). ${ }^{3}$ The first step planning, before the actual review starts, focuses on the analytical framework (Pilbeam et al., 2012). We developed this through a prescreening of the literature and in six interviews with experts from the Swiss Federal Institute of Aquatic Science and Technology (Eawag). The searching step identified the main keywords for the search in the database Scopus. We select an overarching string of keywords constructed with the Boolean connector AND (see Table 1), which functions as a starting point and narrows down our data. As shown in Table 1, we varied the string with synonyms and related terminology (using the Boolean connector OR).

\begin{tabular}{|c|c|c|c|c|}
\hline Attribute & & Governance & & Water system/technology \\
\hline Alternative & AND & Governance & AND & Water \\
\hline OR & & OR & & OR \\
\hline Unconventional & & Public administration & & Urban Water \\
\hline Transformation & & Environmental governance & & Water supply \\
\hline Transition & & Urban governance & & Drinking water \\
\hline Modernization & & Multi-level governance & & Rainwater \\
\hline Deregulation & & Regulation & & Wastewater \\
\hline Decentralization & & Institution & & Public goods \\
\hline Privatization & & Organization & & Network industries \\
\hline Neoliberal & & Management & & Infrastructure industries \\
\hline \multirow[t]{10}{*}{ Reregulation } & & Public service provision & & Utility \\
\hline & & Public policy & & Wastewater treatment \\
\hline & & Policy design & & Technology \\
\hline & & Policy instruments & & Off-grid \\
\hline & & & & No-grid \\
\hline & & & & Onsite \\
\hline & & & & Household \\
\hline & & & & Smart \\
\hline & & & & Small-scale \\
\hline & & & & Distributed \\
\hline
\end{tabular}

Table 1: Keywords used for systematic literature review (own representation)

The results from the screening step were exported to the reference management software Endnote for further review. After the first screening, we analyzed the title, abstract, and keywords of the articles to identify the final sample, which was later fully reviewed and coded. Following the review methodology of Leach and Pelkey (2001), the publications were only included into the sample if they fulfill our four predefined criteria:

1. only peer-reviewed publications due to the verified validity and reliability of their data and results;

2. if they were beneficial for the explanatory value of our analytical framework or if they thematized novel governance arrangements in general, providing information-rich ${ }^{3}$ Similar steps are also described by Wolfswinkel, Furtmueller and Wilderom (2013), who name the steps define, search, select, analyze, and
present. 
cases for the theoretical sampling (Halaweh, Fidler, \& McRobb, 2008; Hughes \& Jones, 2003; Lawrence \& Tar, 2013);

3. only articles published post 1990 were included, due to the shift toward alternative forms in the context of neoliberalism (Lieberherr \& Fuenfschilling, 2016); and

4. only publications that focus on OECD countries or emerging economies are considered. Although developing countries show many cases of technological innovations and alternative governance arrangements, the significantly different institutions and socio-political contexts reduce their applicability for this article (Leach \& Pelkey, 2001).

After selecting our final sample, we coded the publications based on our analytical framework using grounded theory as data analysis method, characterized by the continuous interplay between data collection, reduction, and analysis (Lawrence \& Tar, 2013). During the extraction and synthesis steps, we summarized the information in a spreadsheet format under the predefined categories. The final step reporting discusses the findings by referring back to the research aim and providing insight into how alternative governance modes work in the water sector, which we take on in the next two chapters.

\section{Results and discussion}

After excluding publications that were not related to our area of interest, for example, focusing on water as a conflict resource, water as a human right ("commons"-discourse), water pollution (which is mostly thematized in natural science journals), water allocation, fishery or marine protection, and other infrastructure sectors than water ${ }^{4}$ ), we had a sample with 137 publications. From this sample, we selected a final sample of $11^{5}$ publications that have explanatory value for our analytical framework as they focus on the governancetechnology nexus in relation to the implementation of decentralized, small-scale, or modularized water infrastructure. Nine publications address actual, innovative governance arrangements, and two articles propose new governance arrangements. The selected publications cover eight different countries and varying technologies, as summarized in Table 2.

As for the actual infrastructure of the service provision, most publications described decentralized structures (e.g. decentralized rainwater systems such as stormwater and roofwater harvesting). Some publications described hybrid cases, where centralized and decentralized systems coexist next to each other (e.g. the Japanese on-site wastewater treatment systems can be connected to a central sewer infrastructure) (Gaulke, 2006; Lee, Sarp, Jeon, \& Kim, 2014; Moglia, Alexander, \& Sharma, 2011; Thurston, Taylor, Shuster, Roy, \& Morrison, 2010). However, the infrastructure or the technology was not the publications' area of interest.

\footnotetext{
${ }^{4}$ Especially, the research on the energy and agriculture sector stood out from the sample, as both sectors witnessed re-scaling processes and the implementation of innovative technology, leading to the development of alternative governance arrangements

${ }^{5}$ The 11 publications are an initial choice, which we consider as a pretest for an expanded research.
} 
Concerning the implementation level of the new technology and infrastructure, half of the publications refer to the household level, followed by the municipal and regional level (only 1 publication addressed the national level). Another observation is that the publications focus slightly more on water supply and rainwater management (4 out of 11) than on wastewater and sanitation ( 1 out of 11). However, we can detect a considerable tendency ( 6 out of 11) toward a more holistic approach in the selected literature, which does not treat water supply, wastewater, and rainwater separately, but rather from a more systemic point-of-view, such as water recycling discourse.

\section{Policy instruments}

The publications focus on formal policy instruments, as especially regulatory, but also market- based instruments are proposed more often by the authors and are also applied more frequently in the areas studied than informal instruments. Due to the seemingly wider experience with regulatory and market-based instruments, they are described in far more detail than the informal instruments. The dominance of the formal instruments, however, can also mirror a continuous reliance on legal measures that are enforceable by politicaladministrative actors to guarantee proper operations (Schramm, Kerber, Trapp, Zimmermann, \& Winker, 2017).

\begin{tabular}{|c|c|c|c|c|c|c|}
\hline & Article & Author & Year & Journal & $\begin{array}{l}\text { Country } \\
\text { focus }\end{array}$ & Technology/Infrastructure \\
\hline 1 & $\begin{array}{l}\text { Novel urban water systems } \\
\text { in Germany: governance } \\
\text { structures to encourage } \\
\text { transformation }\end{array}$ & $\begin{array}{l}\text { Schramm } \\
\text { et al. }\end{array}$ & 2017 & $\begin{array}{l}\text { Urban Water } \\
\text { Journal }\end{array}$ & Germany & $\begin{array}{l}\text { Decentralized (at the } \\
\text { household or block level) } \\
\text { and semi-centralized } \\
\text { (quarter level) facilities }\end{array}$ \\
\hline 2 & $\begin{array}{l}\text { Public-private partnerships } \\
\text { as catalysts for community- } \\
\text { based water infrastructure } \\
\text { development: the Border } \\
\text { WaterWorks program in } \\
\text { Texas and New Mexico } \\
\text { colonias }\end{array}$ & Lemos & 2002 & $\begin{array}{l}\text { Environment } \\
\text { and Planning } \\
\text { C: Government } \\
\text { and Policy }\end{array}$ & USA & $\begin{array}{l}\text { Low-technology, low- } \\
\text { maintenance solutions; } \\
\text { household specific } \\
\text { solutions }\end{array}$ \\
\hline 3 & $\begin{array}{l}\text { Inverse infrastructures: } \\
\text { self-organization in the } \\
\text { water services }\end{array}$ & $\begin{array}{l}\text { Heino and } \\
\text { Anttiroiko }\end{array}$ & 2015 & Water Policy & Finland & $\begin{array}{l}\text { Inverse infrastructure (self- } \\
\text { organized micro- } \\
\text { infrastructures); } \\
\text { modularized }\end{array}$ \\
\hline 4 & $\begin{array}{l}\text { Using a reverse auction to } \\
\text { promote household level } \\
\text { stormwater control }\end{array}$ & $\begin{array}{l}\text { Thurston } \\
\text { et al. }\end{array}$ & 2010 & $\begin{array}{l}\text { Environmental } \\
\text { Science \& } \\
\text { Policy }\end{array}$ & USA & $\begin{array}{l}\text { Household level storm } \\
\text { water management; rain } \\
\text { gardens and rain barrels }\end{array}$ \\
\hline 5 & $\begin{array}{l}\text { The sustainability } \\
\text { performance of the water } \\
\text { and sanitation services in } \\
\text { Santiago de Chile }\end{array}$ & $\begin{array}{l}\text { Simon } \\
\text { and Lehn }\end{array}$ & 2012 & $\begin{array}{l}\text { Water Science } \\
\& \text { Technology: } \\
\text { Water Supply }\end{array}$ & Chile & $\begin{array}{l}\text { Conventional residential } \\
\text { and agricultural water } \\
\text { supply }\end{array}$ \\
\hline 6 & $\begin{array}{l}\text { On-site wastewater } \\
\text { treatment and reuses in }\end{array}$ & Gaulke & 2006 & $\begin{array}{l}\text { Urban Water } \\
\text { Journal }\end{array}$ & Japan & $\begin{array}{l}\text { On-site wastewater } \\
\text { treatment "Johkasou" }\end{array}$ \\
\hline
\end{tabular}


Japan

7 Smart water grid: the future water management platform

8 Water Governance in Canada: Innovation and Fragmentation

9 Discussion of the enabling environments for decentralised water systems

10 Source water protection in a landscape of 'New Era' deregulation

11 Smart regulation for water innovation

\author{
Lee et al. 2014 Water \\ Management
}

Bakker

and Cook

Moglia et

Moglia et al.

Patrick

Partzsch
2009

Water Science $\&$ Technology

2009

\section{Desalination and Water \\ Treatment \\ Resources \\ Development}

ournal of Cleaner Production
Australia; "Smart water grid"; ICT

Singapore based cooperation platforms based on selfdiagnosing sensors (pressure and biosensors); risk assessment and forecasting technologies

Canada Conventional residential and agricultural water supply

Australia Decentralized water systems e.g. stormwater and roof-water harvesting, greywater recycling and local treatment facilities

Canada Conventional residential and agricultural water supply

Germany Decentralized rainwater technologies e.g. catchment of rainwater combined with grey water use and recycling

Table 2: Summary of the 11 publications concerning country focus and technology/infrastructure (own representation)

Especially concerning issues of public and environmental health, governmental control seems to remain crucial (Bakker \& Cook, 2011; Patrick, 2009; Schramm et al., 2017). For instance, the lack of oversight over drinking water quality due to deregulation processes was linked to major drinking water incidents in Canada (Bakker \& Cook, 2011; Patrick, 2009). Spreading responsibility thinly among agencies created a situation where no agency was able to take on leadership, leading to harmful consequences due to lack of oversight (Patrick, 2009).

There seems to remain a strong demand for state control over technological innovations or decentralized infrastructure, for example, through monitoring, on-site inspections or groundwater and watershed management in the form of source water protection (Gaulke, 2006; Lee et al., 2014; Patrick, 2009; Schramm et al., 2017; Simon \& Lehn, 2012). The state also remains responsible for regulating the manufacturer (including engineering design codes), installation (including guide- lines and the registration of installers/vendors), monitoring performance, and maintenance and risk assessments (Gaulke, 2006; Moglia et al., 2011). Regulatory measures, however, can also be used to enforce the distribution of a technological innovation by declaring it an industry standard. For instance, the Japanese government issued a specific law (Johkasou Law) for the onsite wastewater treatment system, which specifies who is responsible for implementing and enforcing the technology (Gaulke, 
2006). This law also mandates that new construction in areas without sewers implement the on-site wastewater treatment system Johkasou (ibid). It, thereby, effectively fosters their dissemination. Other suggested measures are concessions, contracts, or sewer system regulations, which are not new, but can contain innovative elements (Patrick, 2009; Schramm et al., 2017; Simon et al., 2012).

In terms of market-based instruments, the articles focus on subsidies and loans, as they can function as a catalyst for an innovation's distribution (Gaulke, 2006; Heino \& Anttiroiko, 2015; Schramm et al., 2017). Other market-based instruments addressed in the literature are procurement auctions and further economic incentives, which have the potential to encourage the adoption of new systems, such as the installation of parcel-scale rain gardens and rain barrels within a small suburban watershed, or support developments in the sector (Thurston et al., 2010; Simon et al., 2012). Thurston, Taylor, Shuster, Roy, and Morrison (2010) have shown that already minimal financial incentives can result in higher willingness to accept the installation of new technologies in the household or on private land. Moreover, also the concept of smart market-based tools consisting of investment grants for decentralized technologies, extraction fees, separate water, and effluent fees as proposed by Partzsch (2009). In addition, Bakker and Cook (2011) provide examples of water markets, full-cost pricing, and accounting for water supply infrastructure to increase the efficiency and financial robustness of public water supplies.

While less frequent, we do find informal measures addressed in our sample. These pertain to, for instance, the provision of expertise (e.g. through state officials) and the information exchange with stakeholders but also between state officials, between water cooperatives or between residents and water providers, sharing, for example, best-practices or good governance approaches (Bakker \& Cook, 2011; Heino \& Anttiroiko, 2015; Lemos, 2002). Educational campaigns, public community meetings, door-to-door meetings, and the direct sending of information to households are other ways to reach stakeholders (Lemos, 2002; Thurston et al., 2010). The literature indicates that a positive effect of conducting ongoing dialogue and critical reviews among a wide range of stake- holders is social learning, which in turn can have a positive impact on the successful introduction and operation of alternative systems (Moglia et al., 2011). Another contagion occurred through "grassroots benchmarking," where neighboring villages in Finland saw the implementation of modular technologies and wanted it as well (Heino \& Anttiroiko, 2015). It seems that informal instruments are particularly favored in the planning phase of new infrastructures, while they lose importance after the implementation phase (Schramm et al., 2017).

Overall, we observe that none of the articles proposes an "ideal" policy instrument but instead they all favor policy instrument mixes: most of the case studies discuss the application of instrument mixes, where the informal instruments can support the formal ones particularly in the initial phases of implementing innovative technologies. This observation is consistent with the literature on policy instruments, which advocates for instrument mixes consisting of formal and informal measures to reach complex environmental goals (Lascoumes \& Le Gales, 2007).

\section{Actors and organizational forms}


Focusing mainly on households, it is not surprising that the local level plays a central role at the actor level, involving especially political-administrative and civil societal actors. It is worth noticing that all articles consider multiple actors in the governance process: the public actors (public departments and agencies) at the regional and national level remain important, as public officials at these levels are responsible to keep an overview of the water systems and for harmonizing standards, for example, drinking water quality. However, we also find that citizens and consumers (local communities) become important players in the context of userdriven modular and decentralized infrastructures (Bakker \& Cook, 2011; Heino \& Anttiroiko, 2015; Simon \& Lehn, 2012).

No single management style stands out over the others. However, our sample contained no case of direct private management, which could be attributed to the perceived importance of state involvement and coheres with the status quo. Key reasons for public organizational forms were arguments that for public and environmental health, direct and in-house control is central (Bakker \& Cook, 2011; Patrick, 2009; Schramm et al., 2017). Ownership was not discussed at length or attributed with particular importance, except in the case of household level installations (Gaulke, 2006; Thurston et al., 2010) or small-scale water cooperatives (Heino \& Anttiroiko, 2015). The latter authors also mentioned organizational forms such as a mutual, social enterprise, and com- munity buy-out as feasible for modularized systems.

\section{Mechanisms}

In terms of accountability, many authors address more horizontal accountability concepts, rather than political-administrative forms. For instance, in the context of modular water systems, non- governmental providers become more accountable to the communities they are working with, while at same time being less accountable to public officials (Lemos, 2002). Accountability vis-à-vis citizens and consumers through public debates and the users' inclusion in the planning process (but also throughout the operation) were found to ensure public acceptance of alternative infrastructures, as these evoke a sense of procedural justice (Lemos, 2002; Moglia et al., 2011; Schramm et al., 2017; Thurston et al., 2010). This form of accountability could lead to less conflict (through ongoing exchange and a platform for debate), while increasing the capacity and confidence of the public to take responsibility for the environment (Moglia et al., 2011). Moreover, it mobilizes actors to support horizontal interactions, which is also important for the principle of collective action (Partzsch, 2009). Collective action in the form of self-organization can be essential, in particular, for the proper operation of user-driven micro-infrastructures (Heino \& Anttiroiko, 2015). For instance, sharing the understanding that everyone in the community will benefit from the collective action could encourage and empower innovation potential, as was found in the Finish context (Heino \& Anttiroiko, 2015). Collective action in turn is interdependent with reputation, reciprocity, and trust (Heino \& Anttiroiko, 2015). Trust as a principle can emerge through the creation of new local democratic procedures and institutions (Bakker \& Cook, 2011). It is also crucial that the interactions with all stakeholders are perceived to be fair, activating the social norm of fairness. Fair procedures are important, because they indicate to community members that they are valued by the actors involved, leading to the acceptance of the authorities' decisions (Moglia et al., 2011). Similarly, the empowerment of local communities was found to be important for running modular and decentralized technology (Bakker \& Cook, 2011; Heino \& Anttiroiko, 2015; Simon \& Lehn, 2012). 
There is little evidence regarding the role of values in the selected publications with two exceptions. For instance, collective action is dependent on activating altruistic values of a com- munity, as it may demand greater solidarity and volunteerism from each community member to run decentralized infrastructures (Moglia et al., 2011). Another example is the use of incentives and fees as a means to activate the egoistic values of actors to change their behavior toward the use of new technologies (Partzsch, 2009).

\section{Conclusion}

Modularized water infrastructures may play an increasingly pivotal role in the water sector due to the need for more flexible and adaptive solutions in urban but also rural areas in the context of climate change and aging infrastructure (Larsen et al., 2016). Departing from the claim that effective application of technology depends on governance systems that enable the integration of innovations in the existing landscape (Tropp, 2007), this article has addressed governance and regulatory arrangements for modular, decentralized, or small-scale water systems. In contrast to the expectation stated in the introduction, we find that alternative governance arrangements largely support a hierarchical understanding of governance, as they attribute the government a super- ordinate role and focus on formal instruments. As such, the governance arrangements are largely not new or alternative as such, but adhere more or less to the status quo of conventional water system governance; they lie more on the government end of the governance to government spectrum (Hysing, 2009). Nonetheless, the literature indicates that informal instruments play an important supplementary role vis-à-vis the formal ones. Moreover, we find that besides the public- administrative actors, civil societal actors in the form of local communities play an important role in the context of modular, decentralized infrastructure. Furthermore, when it comes to the mechanisms, we find a focus on horizontal rather than traditional, vertical political-administrative accountability. Indeed, accountability toward citizens (households) and customers as well as principles such as collective action or trust might gain relevance. This can be linked to the localness of modularized infrastructure. Accordingly, the increasing role of the public at the household and customer level is gaining relevance.

This article is a preliminary step for identifying alternative governance arrangements for modular and decentralized infrastructure in the water sector. We are aware that the small number of considered articles is not enough for conclusive statements or recommendations. Although we included only cases from OECD countries and emerging economies for better comparability, we take into account that the cases still stem from different institutional settings that could interact with the results.

This review provides a stepping-stone for further research. Due to the overall dearth of such alternative arrangements and modular technologies in the water sector, we will take a crosssectoral research approach in a next step. During the literature review, we have already identified some possibly relevant sectors, such as the energy and agricultural sectors. The review has also shown that some elements of our analytical framework seem to contain more explanatory value than others. We will accordingly adapt our analytical framework to be able to identify different types of alternative governance arrangements for modular water infrastructure and ultimately link these to broader considerations on sustainability. Finally, so 
far we have only considered the technological aspect as a contextual factor. In future research, we could focus more on the interplay between governance and technology, which may occur in different directions (technology could drive governance reforms and vice versa). This would be particularly insightful regarding the theory of co-evolution (Crettenand \& Finger, 2013).

\section{Declaration of Conflicting Interests}

The author(s) declared no potential conflicts of interest with respect to the research, authorship, and/or publication of this article.

\section{Funding}

The author(s) disclosed receipt of following financial support for the research, authorship, and/or publication of this article: This work was financially supported by Swiss National Science Foundation (SNF) (ID: 75832).

\section{References}

Araral, E., \& Wang, Y. (2013). Water Governance 2.0: A review and second generation research agenda. Water Resources Management, 27, 3945-3957.

Bakker, K., \& Cook, C. (2011). Water Governance in Canada: Innovation and fragmentation. Water Resources Development, 27, 275-289.

Bovaird, T. (2010). A brief intellectual history of the public-private partnership movement. In G. A. Hodge, C. Greve, \& A. E. Boardman (Eds.), International handbook on public-private partnerships (pp. 43-67). Cheltenham, UK: Edward Elgar Publishing.

Burris, S., Drahos, P., \& Shearing, C. (2005). Nodal Governance. Australian Journal of Legal Philosophy, 30, 30-58.

Crettenand, N., \& Finger, M. (2013). The alignment between institutions and technology in network industries. Competition and Regulation in Network Industries, 14, 106-129.

Dahlgren, E., Göcmen, C., Lackner, K., \& Van Ryzin, G. (2013). Small modular infrastructure. The Engineering Economist, 58, 231-264.

Daniell, K. A., Rinaudo, J. D., Chan, N., Nauges, C., \& Grafton, Q. (2015). Understanding and managing urban water in transition. In Q. Grafton, K. A. Daniell, C. Nauges, J.-D. Rinaudo, \& N. W. W. Chan (Eds.), Understanding and managing urban water in transition (pp. 1-30). Dordrecht: Springer.

Dominguez, D., Worch, H., Markard, J., Truffer, B., \& Gujer, W. (2009). Closing the capability gap: Strategic planning for the infrastructure sector. California Management Review, 51, 30-50.

Finger, M., Groenewegen, J., \& Künneke, R. (2005). The quest for coherence between institutions and technologies in infrastructures. Journal of Network Industries, 6, 227-260.

Gaulke, L. S. (2006). On-site wastewater treatment and reuses in Japan. Water Management, 159,103109. 
Goulden, S., Portman, M. E., Carmon, N., \& Alon-Mozes, T. (2018). From conventional drainage to sustainable stormwater management: Beyond the technical challenges. Journal of Environmental Management, 219, 37-45.

Grigg, N. S. (2011). Water governance: From ideals to effective strategies. Water International, 36, 799-811.

Halaweh, M., Fidler, C., \& McRobb, S. (2008). Integrating the grounded theory method and case study research methodology within is research: A possible 'road map. ICIS 2008 Proceedings. Retrieved May 25, 2018, from https://aisel.aisnet.org/cgi/viewcontent.cgi?article1/41052\& context1/4icis2008

Heino, O., \& Anttiroiko, A. V. (2015). Inverse infrastructures: Self-organization in the water services. Water Policy, 17, 299-315.

Héritier, A. (2002). New modes of Governance in Europe: Policy making without legislating? (Working paper, IHS Political Science Series: 2002, No. 81).

Hodge, G. A., \& Coghill, K. (2007). Accountability in the Privatized State. Governance, 20, 675-702.

Holley, C., Gunningham, N., \& Shearing, C. (2012). The New Environmental Governance. New York: Earthscan.

Holmes, P. R. (2000). Effective organizations for water management. International Journal of Water Resources Development, 16, 57-71.

Hughes, J., \& Jones, S. (2003). Reflections on the use of grounded theory in IS research. ECIS 2003 Proceedings. Retrieved May 25, 2018, from https://aisel.aisnet.org/cgi/viewcontent.cgi? article $1 / 41065 \&$ context $1 / 4$ ecis 2003

Hysing, E. (2009). From government to governance? A comparison of environmental governing in Swedish forestry and transport. Governance, 22, 647-672.

Ingold, K., Lieberherr, E., Schläpfer, I., Steinmann, K., \& Zimmermann, W. (2016). Umweltpolitik der Schweiz -ein Lehrbuch. Zürich: Dike Verlag.

Kinzig, A. P., Ehrlich, P. R., Alston, L. J., Arrow, K., Barrett, S., Buchman, T. G. \& Saari, D. (2013). Social norms and global environmental challenges: The complex interaction of behaviors, values, and policy. Bioscience, 63, 164-175.

Kiparsky, M., Sedlak, D. L., Thompson, B. H., \& Truffer, B. (2013). The innovation deficit in urban water: The need for an integrated perspective on institutions, organizations, and technology. Environmental Engineering Science, 30, 395-408.

Kjær, A. M. (2004). Governance. Cambridge: Polity Press.

Klenk, T., \& Lieberherr, E. (2014). Autonomy in public service provision and the challenge of accountability: Insights from German policy fields (Jerusalem Papers in Regulation \& Governance, Working Paper No. 66).

Krozer, Y., Hophmayer-Tokich, S., van Meerendonk, H., Tijsma, S., \& Vos, E. (2010). Innovations in the water chain - experiences in The Netherlands. Journal of Cleaner Production, 18, 439-446.

Larsen, T. A., Hoffmann, S., Lüthi, C., Truffer, B., \& Maurer, M. (2016). Emerging solutions to the water challenges of an urbanizing world. Science, 352, 928-933.

Larsen, T. A., Lienert, J., \& Udert, K. M. (Eds.). (2013). Source separation and decentralization for wastewater treatment. London: IWA Publishing.

Lascoumes, P., \& Le Gales, P. (2007). Introduction: Understanding public policy through its instruments-from the nature of instruments to the sociology of public policy instrumentation. Governance, 20, 1-21.

Lawrence, J., \& Tar, U. (2013). The use of grounded theory technique as a practical tool for qualitative data collection and analysis. The Electronic Journal of Business Research Methods, $11,29-40$. 
Leach, W. D., \& Pelkey, N. W. (2001). Making watershed partnerships work: A review of the empirical literature. Journal of Water Resources Planning and Management, 127, 378-385.

Lee, S. W., Sarp, S., Jeon, D. J., \& Kim, J. H. (2014). Smart water grid: The future water management platform. Desalination and Water Treatment, 55, 339-346.

Lemos, M. C. (2002). Public-private partnerships as catalysts for community-based water infrastructure development: The Border WaterWorks program in Texas and New Mexico colonias. Environment and Planning C: Government and Policy, 20, 281-295.

Lieberherr, E. (2012). Transformation of water governance and legitimacy: Comparing Swiss, German and English water supply and sanitation service providers. Doctoral thesis, Lausanne: Swiss Federal Institute of Technology, Lausanne.

Lieberherr, E., \& Fuenfschilling, L. (2016). Neoliberalism and sustainable urban water sectors: A critical reflection of sector characteristics and empirical evidence. Environment and Planning C: Politics and Space, 34, 1540-1555.

Lieberherr, E., Klinke, A., \& Finger, M. (2012). Towards legitimate water governance? The partially privatized Berlin waterworks. Public Management Review, 14, 923-946.

Lieberherr, E., \& Truffer, B. (2015). The impact of privatization on sustainability transitions: A comparative analysis of dynamic capabilities in three water utilities. Environmental Innovation and Societal Transitions, 15, 101-122.

Lundqvist, L. J. (2001). Implementation from above: The ecology of power in Sweden's environmental governance. Governance, 14, 319-337.

Markard, J. (2011). Transformation of infrastructures: Sector characteristics and implications for fundamental change. Journal of Infrastructure Systems, 17, 107-117.

Ménard, C., \& Saleth, R. M. (2012). The effectiveness of alternative water governance arrange- ments. In M. Young \& C. Esau (Eds.), Investing in water for a green economy (pp. 152-174). London: United Nations Environment Program/Routledge.

Moglia, M., Alexander, K. S., \& Sharma, A. (2011). Discussion of the enabling environments for decentralised water systems. Water Science \& Technology, 63, 2331-2339.

Moshinsky, A., \& Bar-Hillel, M. (2010). Loss aversion and status quo label bias. Social Cognition, 28, 191-204.

OECD. (2007). Infrastructure to 2030: Mapping policy for electricity, water and transport (Vol. 2). Paris: Organization for Economic Co-operation and Development. Retrieved May 15, 2018 from https://www.oecd.org/futures/infrastructureto2030/40953164.pdf

OECD. (2009). Managing water for all. An OECD perspective on pricing and financing. Paris: Organization for Economic Co-operation and Development. Retrieved May 15, 2018 from http://www.oecd.org/tad/sustainable-agriculture/44476961.pdf

Pahl-Wostl, C. (2007). Transition towards adaptive management of water facing climate and global change. Water Resource Management, 21, 49-62.

Partzsch, L. (2009). Smart regulation for water innovation - The case of decentralized rainwater technology. Journal of Cleaner Production, 17, 985-991.

Patrick, R. J. (2009). Source water protection in a landscape of 'New Era' deregulation. The Canadian Geographer / Le Géographe canadien, 53, 208-221.

Pérard, E. (2009). Water supply: Public or private?. Policy and Society, 27, 193-219.

Pierre, J., \& Peters, B. G. (2000). Governance, politics and the state. New York: St. Martin's Press.

Pilbeam, C., Alvarez, G., \& Wilson, H. (2012). Extending sustainability to suppliers: A systematic literature review. Supply Chain Management: An International Journal, 17, 531-543. 
Piskorski, M. J., \& Gorbatai, A. D. (2017). Testing Coleman's social norm enforcement mechanism: Evidence from Wikipedia. American Journal of Sociology, 122, 1183-1222.

Potts, J. (2009). The innovation deficit in public services: The curious problem of too much efficiency and not enough waste and failure. Innovation: Management, Policy \& Practice, 11, 34-43. Purtik, H., \& Arenas, D. (2017). Embedding social innovation: Shaping societal norms and behaviors throughout the innovation process. Business \& Society, 1-40.

Rhodes, R. A. W. (1996). The New Governance: Governing without Government. Political Studies, $44,652-667$.

Rhodes, R. A. W. (2007). Understanding Governance: Ten Years On. Organization Studies, 28, $1243-$ 1264.

Schneider, V., \& Jäger, A. (2001). The privatisation of infrastructures in the theory of the state: An empirical overview and a discussion of competing theoretical explanations. Workshop paper, Regulatory Reform at the 29th Joint Sessions of Workshops (ECPR), 2001, Grenoble, France.

Schramm, E., Kerber, H., Trapp, J. H., Zimmermann, M., \& Winker, M. (2017). Novel urban water systems in Germany: Governance structures to encourage transformation. Urban Water Journal, $1-10$.

Simon, L. M., \& Lehn, H. (2012). The sustainability performance of the water and sanitation services in Santiago de Chile. Water Science \& Technology: Water Supply, 12, 854-861.

Sørensen, E. (2006). Metagovernance. The changing role of politicians in processes of democratic governance. American Review of Public Administration, 36, 98-114.

Steg, L., Perlaviciute, G., van der Werff, E., \& Lurvik, J. (2014). The significance of hedonic values for environmentally relevant attitudes, preferences, and actions. Environment and Behavior, 46, 163-192.

Stoker, G. (1998). Governance as theory: five propositions. International Social Science Journal, 50, $17-28$.

Thom, N., \& Ritz, A. (2006). Public Management: Innovative Konzepte zur Führung im öffentlichen Sektor. Wiesbaden: Gabler.

Thurston, H. W., Taylor, M. A., Shuster, W. D., Roy, A. H., \& Morrison, M. A. (2010). Using a reverse auction to promote household level stormwater control. Environmental Science \& Policy, 13, 405-414.

Trapp, J. H., Kerber, H., \& Schramm, E. (2017). Implementation and diffusion of innovative water infrastructures: Obstacles, stakeholder networks and strategic opportunities for utilities. Environmental Earth Sciences, 76, 1-14.

Tropp, H. (2007). Water governance: Trends and needs for new capacity development. Water Policy, 9, 19-30.

Truffer, B., Binz, C., Gebauer, H., \& Sto r̈mer, E. (2013). Market success of on-site treatment: A systemic innovation problem. In T. A. Larsen, K. M. Udert, \& J. Lienert (Eds.), Wastewater treatment: Source separation and decentralisation (pp. 209-223). London: IW A Publishing.

van de Meene, S. J., Brown, R. R., \& Farrelly, M. A. (2011). Towards understanding governance for sustainable urban water management. Global Environmental Change, 21, 1117-1127.

von Tunzelmann, N. (2003). Historical coevolution of governance and technology in the industrial revolutions. Structural Change and Economic Dynamics, 14, 365-384.

Wolfswinkel, J. F., Furtmueller, E., \& Wilderom, C. P. (2013). Using grounded theory as a method for rigorously reviewing literature. European Journal of Information Systems, 22, 45-55. 